\title{
Monotypic plasma cells in labial salivary glands of patients with Sjögren's syndrome: Prognosticator for systemic lymphoproliferative disease
}

C Bodeutsch, P C M de Wilde, L Kater, F H J van den Hoogen, R J Hené, J C van Houwelingen, L B A van de Putte, G P Vooijs

\begin{abstract}
Aims: To determine the prevalence of plasma cell monotypia in labial salivary gland tissue of patients with and without Sjögren's syndrome, and to evaluate its relation to the development of systemic monoclonal lymphoproliferative disorders.
\end{abstract}

Methods: A quantitative immunohistological study was performed on labial salivary gland tissue of 45 patients with Sjögren's syndrome, 18 with rheumatoid arthritis without Sjögren's syndrome, and 80 healthy controls. In none of the patients with Sjögren's syndrome was there evidence of systemic monoclonal lymphoproliferative disease at the time of biopsy.

Results: Monotypic plasma cell populations, defined by a $\kappa: \lambda$ ratio of $\geqslant 3$, were only observed in older patients (above 43 years) with Sjögren's syndrome. In almost all these patients monotypic plasma cell populations were present in multiple labial salivary gland tissues and the $I g M / \kappa$ monotypia was observed most frequently. The prevalence of monotypic plasma cell populations in the group with Sjögren's syndrome was $22 \%(10 / 45)$ and there was no significant predilection for primary Sjögren's syndrome. Of special clinical interest was the observation that progression to systemic monoclonal lymphoproliferative disease had occurred exclusively in this subgroup of patients with Sjögren's syndrome, with a prevalence of $30 \%$ (3/10).

Conclusion: Quantitative immunohistological examination of labial salivary gland tissues provides pathologists with a simple method to select those patients with Sjögren's syndrome who have an increased relative risk at the time of biopsy to develop benign or malignant lymphoproliferative disorders.

(F Clin Pathol 1993;46:123-128)

Sjögren's syndrome has often been regarded as a link in the spectrum between autoimmune disease and lymphoproliferative disorders. ${ }^{1-3}$ Polyclonal B cell activation, characterised by hypergammaglobulinaemia and autoantibody formation, such as rheumatoid factors, antinuclear antibodies, and antibodies to Ro/SS-A and La/SS-B, is a common finding in Sjögren's syndrome..$^{2-7}$ It is well known that benign or malignant systemic monoclonal gammopathy, or malignant lymphoma, may evolve from a polyclonal lymphoproliferative process in Sjögren's syndrome. ${ }^{389}$ An epidemiological study has shown that the relative risk of developing malignant lymphoma in Sjögren's syndrome is about 44 times higher than in the normal population. ${ }^{10}$ In this study the risk of malignant lymphoma was similar for primary Sjögren's syndrome and secondary Sjögren's syndrome, although other investigators believe malignant lymphoma to be more common in primary Sjögren's syndrome. ${ }^{3}$

Although a sudden decrease in serum immunoglobulin concentration has been recognised as a portent of malignant transformation, ${ }^{2311}$ when Sjögren's syndrome is diagnosed it is not possible to detect patients prone to such a transformation.

Much more promising with regard to predicting malignant transformation in such patients were the observations that extrasalivary gland non-Hodgkin's lymphomas occurred exclusively in patients with Sjögren's syndrome and a myoepithelial sialadenitis of the major salivary glands with monotypic $B$ cell proliferation areas, but not in those with polytypic B cell proliferation areas. ${ }^{112}$ However, these very interesting findings are of relatively little clinical importance, as the labial salivary gland tissue biopsy specimen is much more widely used to diagnose Sjögren's syndrome than the major salivary gland biopsy specimen.

In a recent study monoclonal plasma cell populations, defined by a $\kappa: \lambda$ ratio of $\geqslant 3$ have been demonstrated in labial salivary gland tissues of more than $50 \%$ of patients with Sjögren's syndrome with concomitant monoclonal cryoglobulinemia. ${ }^{13}$

However, findings from systematic studies on the prevalence of monotypic plasma cell populations in the labial salivary gland tissues of patients with Sjögren's syndrome without systemic monoclonal lymphoproliferative disorders at the time of biopsy, and their association with progression into the latter disorders, have never been published.

\section{Methods}

Labial salivary gland tissue biopsy specimens from 143 subjects were used (table 1). Group I comprised 80 healthy control subjects free of systemic diseases, who underwent intraoral surgery for cosmetic or preprosthetic purposes; 
Table 1 Clinical details of subjects studied

\begin{tabular}{|c|c|c|}
\hline $\begin{array}{l}\text { Group } \\
\text { (mean age, range) }\end{array}$ & $n=$ & Diagnosis \\
\hline I $(37 \cdot 7$ years $0-78$ years $)$ & 80 & $\begin{array}{l}\text { Healthy controls: intraoral surgery for cosmetic or } \\
\text { preprosthetic purposes; no evidence of systemic } \\
\text { disease. }\end{array}$ \\
\hline II ( 58.6 years $42-78$ years) & 18 & $\begin{array}{l}\text { Rheumatoid arthritis: volunteers without subjective } \\
\text { ocular or oral dryness, or salivary gland swellings, } \\
\text { clinically not suspected of having Sjögren's } \\
\text { syndrome. }\end{array}$ \\
\hline III ( 50.5 years $14-76$ years) & 45 & $\begin{array}{l}\text { Sjögren's syndrome: keratoconjunctivitis sicca } \\
\text { focal lymphocytic adenitis of the labial salivary } \\
\text { glands with a lymphocytic focus score of }>1 \text { and } \\
\text { serological abnormalities, }+ \text { Xerostomia was } \\
\text { present in } 43 / 45 \text { patients; } 35 \text { patients had primary } \\
\text { Sjögren's syndrome, } 10 \text { had secondary Sjögren's } \\
\text { syndrome: } 4 \text { with rheumatoid arthritis, } 2 \text { with } \\
\text { mixed connective tissue disease, } 2 \text { with systemic } \\
\text { sclerosis, } 1 \text { with primary biliary cirrhosis, and } 1 \\
\text { with chronic discoid lupus erythematosus }\end{array}$ \\
\hline
\end{tabular}

„Examination through slit lamp and at least two tests positive for the following: Schirmer's test $<5 \mathrm{~mm} / 5 \mathrm{~min}$, van Bijsterveld's score of $>3$, tear break up time of $<10$ seconds, decreased tear lysozyme or lactoferrin concentration. In five patients only Schirmer's test was performed. tIncrease in serum IgA, serum IgG, or serum IgM, and/or presence of autoantibodies (rheumatoid factor and/or antinuclear antibody and/or anti-SS-A and/or anti-SS-B).

group II comprised 18 patients with rheumatoid arthritis (RA) without sicca disorders, who were willing to undergo a lip biopsy. Both served as control groups. Group III consisted of 45 patients with Sjögren's syndrome, 35 with primary Sjögren's syndrome, and 10 with secondary Sjögren's syndrome. All patients with RA fulfilled the criteria defined by the American Rheumatism Association. ${ }^{14}$ The diagnosis of Sjögren's syndrome was based on the presence of ophthalmologically confirmed keratoconjunctivitis sicca, ${ }^{15}$ and a grade IV focal sialoadenitis was based on the scale of Chisholm and Mason, ${ }^{16}$ corresponding with a lymphocytic focus score of more than one lymphocytic focus per $4 \mathrm{~mm}^{2}$ labial salivary gland tissue. More relevant clinical information about the patients is given in table 1 .

All labial salivary gland tissue biopsy specimens were obtained using the horizontal incision technique described by Greenspan et al. ${ }^{17}$ Informed consent was obtained. None of the subjects had evidence of a systemic benign or malignant monoclonal disorder or malignant lymphoma at the time of labial salivary gland tissue biopsy.

All biopsy specimens were fixed in a formol sublimate solution ${ }^{1819}$ and embedded in paraffin wax. Histological examination and lymphocytic focus scoring were performed on haematoxylin and eosin stained sections. In addition, serial $5 \mu \mathrm{m}$ sections were stained with a peroxidase-antiperoxidase diaminobenzidine (PAP/DAB) technique to visualise IgA, IgG, IgM, $\kappa$, and $\lambda$ containing plasma cells. Technical details of the PAP/DAB technique are summarised in table 2 . In cases where monoclonicity of the plasma cellular infiltrate was suspected on the basis of the immunoperoxidase staining results, double immunofluorescence labelling with antibodies against heavy and light chains $(\operatorname{Ig} A / \kappa, \operatorname{Ig} A / \lambda, \operatorname{IgG} / \kappa, \operatorname{IgG} / \lambda$, $\operatorname{IgM} / \kappa$, and $\operatorname{IgM} / \lambda$ ) was performed on $5 \mu \mathrm{m}$ serial paraffin wax sections.

The following five quantitative immunohistological parameters were obtained from measurements in 30 to $\mathbf{4 0}$ systematically sampled test fields of $0.04 \mu \mathrm{m}$ : the mean numbers of IgA, IgG, IgM, $\kappa$, and $\lambda$ containing plasma
Table 2 Immunoperoxidase procedures used

\begin{tabular}{|c|c|}
\hline & $\begin{array}{l}\text { Dewaxing and rehydration } \\
\text { Removing of mercury pigment by immersion in } \\
\text { Lugol's iodine ( } 5 \mathrm{~min} \text { ) }\end{array}$ \\
\hline 3 & $\begin{array}{l}\text { Blocking of endogenous peroxidase in methanol } \\
\text { containing } 1 \% \text { hydrogen peroxide ( } 30 \mathrm{~min})\end{array}$ \\
\hline & $\begin{array}{l}\text { Preincubation with normal swine serum ( } 20 \mathrm{~min}) \\
\text { Incubation with diluted monospecific antisera against } \\
\text { IgA ( } 1 \text { in } 800) \text {, IgG ( } 1 \text { in } 200) \text {, IgM ( } 1 \text { in } 800) \text {, } \\
\kappa(1 \text { in } 2400) \text { and } \lambda(1 \text { in } 2400) \text { ( } 1 \text { hour) }\end{array}$ \\
\hline & $\begin{array}{l}\text { Incubation with diluted swine anti-rabbit serum } \\
(1 \text { in } 20)(30 \mathrm{~min})\end{array}$ \\
\hline & $\begin{array}{l}\text { ith dilute } \\
0 \text { min) }\end{array}$ \\
\hline 8 & $\begin{array}{l}\text { ent of peroxid } \\
\text { men peroxide ( }\end{array}$ \\
\hline & $\begin{array}{l}\text { Counterstain with Mayer's haematoxylin, dehydrate, } \\
\text { and mount in DPX }\end{array}$ \\
\hline \multicolumn{2}{|c|}{$\begin{array}{l}\text { Antisera diluted in phosphate buffered saline (pH } 7 \cdot 4) \\
\text { containing } 1 \% \text { bovine serum albumin; optimal dilutions } \\
\text { found by chess board titration; incubations at room } \\
\text { temperature. All antisera were purchased from Dakopatts, } \\
\text { Denmark. Specificity of all antisera was confirmed by } \\
\text { appropriate laboratory tests and on monoclonal plasma cells } \\
\text { in bone marrow biopsy specimens obtained from related } \\
\text { patients with myeloma. }\end{array}$} \\
\hline
\end{tabular}

cells per $0.04 \mathrm{~mm}^{2}$ labial salivary gland tissue. From these parameters the percentages of $\operatorname{IgA}$, IgG, IgM and $\kappa$ containing plasma were calculated and will be further designated $\% \operatorname{IgA}, \% \operatorname{IgG}, \% \operatorname{IgM}$, and $\% \kappa$. The procedure for quantification of positive plasma cells and tissue sampling has been described in detail elsewhere. $^{20}$

The following serological tests were performed on patients in groups II and III: immunoelectrophoresis, serum IgA, IgG, and IgM concentration (radial immunodiffusion or nephelometry), presence and type of paraproteins, cryoglobulins, rheumatoid factor (Rose-Waaler test), antinuclear antibodies (indirect immunofluorescence on frozen mouse liver sections), anti-SS-A and anti-SS-B (western blotting).

In statistical analyses $\% \kappa$ was used instead of $\kappa: \lambda$ ratio as the former looks much more like a normally distributed variable due to the absence of skewness. Student's $t$ test for unpaired observations or the $\chi^{2}$ test were used to compare histological, immunohistological, and serological parameters, and the clinical course of different groups.

Details of clinical follow up were obtained from the case records of the patients with Sjögren's syndrome.

\section{Results}

QUANTITATIVE STUDY

Five quantitative immunohistological parameters are used to quantify the composition of the plasma cellular infiltrates in labial salivary gland tissue. These five parameters are: the mean \%IgA, \%IgG, \%IgM, \% $\kappa$ containing plasma cells and the mean number of light chain containing plasma cells per $0.04 \mathrm{~mm}^{2}$ labial salivary gland tissue $(\kappa+\lambda)$. These five parameters in patients with RA (group II) were not significantly $(p>0.05)$ different from those of the group of healthy controls (group I); these five parameters in patients with Sjögren's syndrome (group III) differed significantly from those of healthy controls and patients with RA (table 3). There were no 
Table 3 Comparison of quantitative immunohistological results in labial salivary gland tissue of patients and controls

\begin{tabular}{llllll}
\hline & $\begin{array}{l}\text { Group I }(n=80) \\
\text { mean }(S D)\end{array}$ & $\begin{array}{l}\text { Group II }(n=18) \\
\text { mean }(S D)\end{array}$ & $\begin{array}{l}\text { Group III }(n=45) \\
\text { mean }(S D)\end{array}$ & $\begin{array}{l}\text { Primary Sjögren's } \\
\text { syndrome }(n=35) \\
\text { mean }(S D)\end{array}$ & $\begin{array}{l}\text { Secondary Sjögren's } \\
\text { syndrome }(n=10) \\
\text { mean }(S D)\end{array}$ \\
\hline$\% \kappa$ & $59 \cdot 1(4 \cdot 3)$ & $59 \cdot 1(4 \cdot 9)$ & $66 \cdot 7(9 \cdot 9) \dagger$ & $66 \cdot 7(10 \cdot 1)$ & $66 \cdot 9(10 \cdot 0)$ \\
$\kappa+\lambda$ & $22 \cdot 0(10 \cdot 0)$ & $24 \cdot 9(8 \cdot 1)$ & $80 \cdot 1(41 \cdot 0)^{\star}$ & $86 \cdot 9(43 \cdot 1)$ & $56 \cdot 4(20 \cdot 0) \ddagger$ \\
$\% I g A$ & $88 \cdot 3(7 \cdot 7)$ & $86 \cdot 4(9 \cdot 4)$ & $42 \cdot 2(17 \cdot 1)^{\star}$ & $43 \cdot 1(17 \cdot 9)$ & $39 \cdot 1(14 \cdot 2)$ \\
\%IgG & $8 \cdot 3(6 \cdot 0)$ & $8 \cdot 3(5 \cdot 1)$ & $33 \cdot 6(13 \cdot 3)^{\star}$ & $35 \cdot 2(13 \cdot 7)$ & $27 \cdot 7(10 \cdot 6)$ \\
$\% \operatorname{lgM}$ & $3 \cdot 4(3 \cdot 8)$ & $5 \cdot 3(6 \cdot 1)$ & $24 \cdot 3(21 \cdot 4)^{\star}$ & $21 \cdot 7(21 \cdot 3)$ & $33 \cdot 3(20 \cdot 2)$ \\
\hline
\end{tabular}

$\% \kappa, \% \operatorname{IgA}, \% \mathrm{IgG}, \% \mathrm{IgM}=$ percentage of $\kappa, \operatorname{IgA}, \mathrm{IgG}$, and IgM containing plasma cells in the labial salivary gland tissue.

$\kappa+\lambda=$ total number of $\kappa$ and $\lambda$ containing plasma cells per $0.04 \mathrm{~mm}^{2}$ labial salivary gland tissue

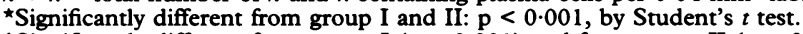

†Significantly different from group I ( $<<0.001)$ and from group II $(p=0.02)$, by Student's $t$ test.

$\ddagger$ Significantly different from primary Sjögren's syndrome $(p=0.003)$, by Student's $t$ test.

Figure 1 Percentages of $\kappa$ containing plasma cells of all subjects in this study. Dotted horizontal lines define the pooled $99.8 \%$ confidence interval (mean $\pm 3 x S D)$ of the control groups $I$ and II. Ten patients with Sjögren's syndrome were beyond this confidence interval.

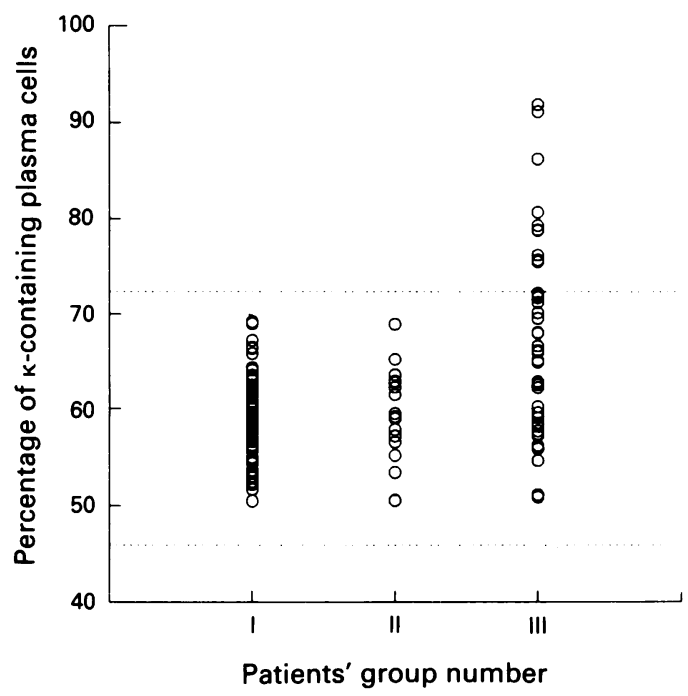

significant differences $(p>0 \cdot 10)$ between primary Sjögren's syndrome and secondary Sjögren's syndrome with regard to \%IgA, $\%$ IgG, \%IgM and \% $\%$. In primary Sjögren's syndrome the numerical density of light chain containing plasma cells $(\kappa+\lambda)$ was significantly higher than in secondary Sjögren's syndrome $(\mathrm{p}=0.003)$ (table 3$)$.

Figure 1 shows $\% \kappa$ in the labial salivary gland tissue biopsy specimens of all subjects of the three groups. The normal range of $\% \kappa$ (determined in groups I and II and set at the mean \pm 3 standard deviations) was
$45 \cdot 9 \%-72 \cdot 3 \%$. In 10 patients with Sjögren's syndrome $\% \kappa$ was out of the normal range (fig $1)$. All these patients had an excess of $\kappa$ containing plasma cells, with at least $75.5 \% \kappa$ containing plasma cells in the labial salivary gland tissue (range $\% \kappa: 75 \cdot 5 \%-91 \cdot 1 \%$ ). A $\% \kappa$ of $\geqslant 75$ was found in eight of 35 patients with primary Sjögren's syndrome and in two of 10 with secondary Sjögren's syndrome. The difference in prevalence of $\% \kappa$ of $\geqslant 75$ between primary Sjögren's syndrome and secondary Sjögren's syndrome was not significant ( $p=$ $0 \cdot 8)$. The population of patients with Sjögren's syndrome (group III) were divided in two subpopulations, group IIIA with $\% \kappa$ of $\geqslant 75$ and group IIIB with $\% \kappa$ of $<75$.

Table 4 shows that patients with abnormal $\% \kappa$ also had significantly higher $\% \operatorname{IgM}(\mathrm{p}=$ 0.002 ), significantly lower \%IgA and \%IgG $(p \leqslant 0.005)$, and a significantly higher lymphocytic focus score $(p=0.006)$. There was no significant difference $(p=0.93)$ between these two subgroups of Sjögren's syndrome with regard to the total numerical density of plasma cells $(\kappa+\lambda)$ in the labial salivary gland tissue (table 4 ). The relation between high percen-. tages of $\kappa$ and IgM containing plasma cells is clearly shown in the scatter diagram of fig 2 .

Table 4 shows that the serum IgA and IgG concentrations in the patients with Sjögren's syndrome of group IIIA were significantly lower than in the patients in group IIIB, with $P$ values of 0.01 and 0.0005 , respectively. Fur-

Table 4 Histological, immunohistological and serological results in patients with Sjögren's syndrome compared with abnormal (group IIIA) and normal (group IIIB) percentage $\kappa$ containing plasma cells in labial salivary gland tissue

\begin{tabular}{llll} 
& $\begin{array}{l}\text { Group IILA } \\
(n=10)\end{array}$ & $\begin{array}{l}\text { Group IIIB } \\
(n=35)\end{array}$ & $p$ Value \\
\hline LSG parameter: (Student's $t$ test) & Mean (SD) & Mean (SD) & \\
\%kappa & $81 \cdot 4(6 \cdot 2)$ & $62 \cdot 5(5 \cdot 9)$ & $\mathrm{nr}$ \\
$\kappa+\lambda$ & $79 \cdot 1(32 \cdot 0)$ & $80 \cdot 4(43 \cdot 6)$ & $0 \cdot 93$ \\
\%IgA & $28 \cdot 4(14 \cdot 4)$ & $47 \cdot 1(14 \cdot 5)$ & $0 \cdot 0001$ \\
\%IgG & $23 \cdot 5(15 \cdot 4)$ & $36 \cdot 4(1 \cdot \cdot 4)$ & $0 \cdot 005$ \\
\%IgM & $51 \cdot 7(25 \cdot 3)$ & $16 \cdot 5(11 \cdot 9)$ & $0 \cdot 002$ \\
Lymphocytic focus score & $5 \cdot 3(2 \cdot 1)$ & $3 \cdot 4(1 \cdot 8)$ & $0 \cdot 006$ \\
Serum Ig: & & & \\
IgA (g/) & $2 \cdot 2(0 \cdot 9)$ & $3 \cdot 3(1 \cdot 7)$ & $0 \cdot 012$ \\
IgG (g/l) & $12 \cdot 4(5 \cdot 0)$ & $21 \cdot 1(9 \cdot 4)$ & $0 \cdot 0005$ \\
IgM (g/l) & $2 \cdot 8(1 \cdot 3)$ & $2 \cdot 2(1 \cdot 5)$ & $0 \cdot 30$ \\
Incidence of: $\chi^{2}$ test & & & \\
Salivary gland swelling & $4 / 10$ & $13 / 35$ & $0 \cdot 87$ \\
Cryoglobulinemia & $5 / 10$ & $2 / 27$ & $0 \cdot 003$ \\
Rheumatoid factor & $3 / 7$ & $23 / 34$ & $0 \cdot 22$ \\
Antinuclear antibody & $6 / 10$ & $26 / 35$ & $0 \cdot 38$ \\
Anti-SS-A & $4 / 10$ & $9 / 32$ & $0 \cdot 48$ \\
Anti-SS-B & $4 / 10$ & $15 / 32$ & $0 \cdot 70$ \\
Serum IgG > 13.3 g/l & $4 / 10$ & $28 / 35$ & $0 \cdot 03$ \\
\hline
\end{tabular}

$\kappa+i=$ total number of $\kappa$ and $i$ containing plasma cells per $0.04 \mathrm{~mm}^{2}$ labial salivary gland

\%kappa, \%IgA, \%IgG, \% IgM are percentages of $\kappa$, IgA, IgG, and IgM containing plasma cells in labial salivary gland tissue

$\mathrm{nr}=$ not relevant, as $\% \kappa$ was used to select the two subgroups of Sjögren's syndrome patients.

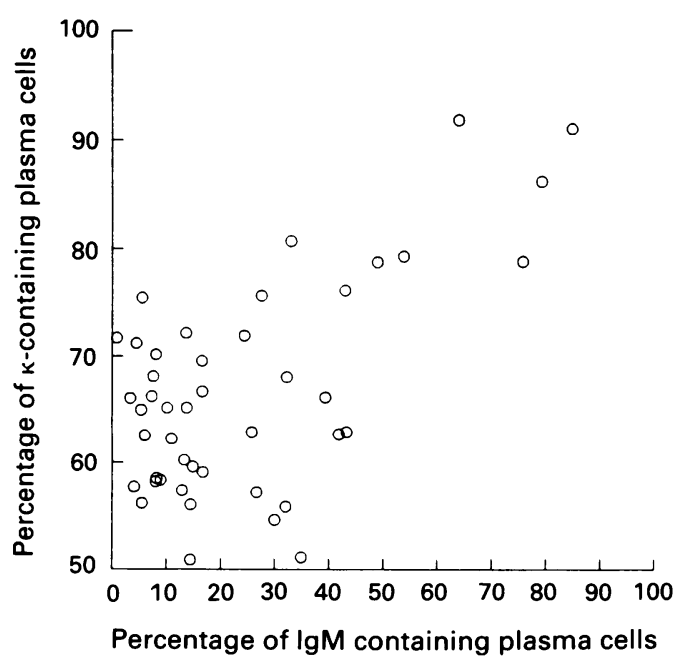

Figure 2 Scatter diagram of \% containing plasma cells compared with \%IgM containing plasma cells of patients with Sjögren's syndrome. 
thermore, polyclonal cryoglobulinaemia was found significantly more often in patients with Sjögren's syndrome of group IIIA $(p=0.003)$. The prevalence of normal serum IgG titres $(\mathrm{IgG}<13.3 \mathrm{~g} / \mathrm{l})$ was significantly higher in group IIIA than in group IIIB patients $(p=$ 0.03).

The scatter diagram in fig 3 shows that all patients with Sjögren's syndrome with $\% \kappa$ of $\geqslant 75$ (group IIIA) were older than 43 years. Under the assumption that there is no age predominance for this phenomenon one would expect that four of the 18 patients with Sjögren's syndrome younger than 43 years would have a $\% \kappa$ of $\geqslant 75$. Group II patients had the same age distribution as group IIIA patients, but in the former group none of the patients had abnormal $\% \kappa$ values, despite the presence of lymphocytic adenitis in $89 \%$ of them (table 5).

\section{QUALITATIVE STUDY}

In the 10 patients with Sjögren's syndrome with $\% \kappa$ of $\geqslant 75$ (group IIIA) the results of immunoperoxidase staining of the labial salivary gland tissue biopsy specimens gave rise to suspicion of monotypic plasma cell populations within the infiltrate. In eight of these patients $\kappa$ containing plasma cells predominated throughout all the glands of the biopsy specimen.

In one patient the biopsy specimen, comprising four glands, had a predominance of $\mathrm{IgG} / \kappa$ containing plasma cells in two glands; in the other two glands there was no suspicion of monotypic plasma cells. In another patient the biopsy specimen, consisting of nine glands, showed predominance of $\operatorname{IgA} / \kappa$ containing plasma cells in one gland and predominance of $\operatorname{IgM} / \kappa$ containing plasma cells in the other glands.

In seven of the 10 patients with Sjögren's syndrome with $\% \kappa$ of $\geqslant 75$ the labial salivary gland tissue was available for double immunofluorescence labelling. This confirmed the presence of monotypic plasma cell populations within the infiltrates in all seven cases. In six cases the monotypic plasma cell populations were of IgM/ $/$ type and in one case of both $\operatorname{IgM} / \kappa$ and $\operatorname{IgA} / \kappa$ (table 6 ). Serological, histological, and immunohistological findings of the 10 patients with Sjögren's syndrome with an abnormal $\% \kappa$ in the labial salivary gland tissue are also shown in table 6 .

\section{FOLLOW UP STUDY}

Two of the 10 patients with Sjögren's syndrome with an excess of $\kappa$ containing plasma cells in the labial salivary gland tissue devel-

Table 5 Mean ages and percentage of $\kappa$ containing plasma cells in labial salivary gland tissue in all patients and controls

\begin{tabular}{|c|c|c|c|c|c|}
\hline \multirow{2}{*}{$\begin{array}{l}\text { Group } \\
\text { I (Healthy controls) } \\
\text { II (RA) } \\
\text { I + II } \\
\text { IIIA (SS, \%kappa >75) } \\
\text { IIIB (SS, \%kappa <75) }\end{array}$} & \multicolumn{3}{|c|}{$N$ Mean age (range) } & \multicolumn{2}{|c|}{ Mean \%א (range) } \\
\hline & $\begin{array}{l}80 \\
18 \\
98 \\
10 \\
35 \\
45\end{array}$ & $\begin{array}{l}37 \cdot 7 \\
58 \cdot 6 \\
41 \cdot 6 \\
59 \cdot 8 \\
47 \cdot 8 \\
50 \cdot 5\end{array}$ & $\begin{array}{l}(0-78) \\
(42-78) \\
(0-78) \\
(44-73) \\
(14-76) \\
(14-76)\end{array}$ & $\begin{array}{l}59 \cdot 1 \\
59 \cdot 1 \\
59 \cdot 1 \\
81 \cdot 4 \\
62 \cdot 5 \\
66 \cdot 7\end{array}$ & $\begin{array}{l}(50 \cdot 5-69 \cdot 2) \\
(50 \cdot 5-69 \cdot 0) \\
(50 \cdot 5-69 \cdot 2) \\
(75 \cdot 5-91 \cdot 9) \\
(50 \cdot 9-72 \cdot 2) \\
(50 \cdot 9-91 \cdot 9)\end{array}$ \\
\hline
\end{tabular}

$\mathrm{RA}=$ rheumatoid arthritis; SS $=$ Siögren's syndrome; \%kappa $=$ percentage of $\kappa$ containing plasma cells in labial salivary gland tissue.
- control group

$\triangle$ Sjögren's syndrome: group with \%k of $<75$

- Sjögren's syndrome: group with \%k of $\geq 75$

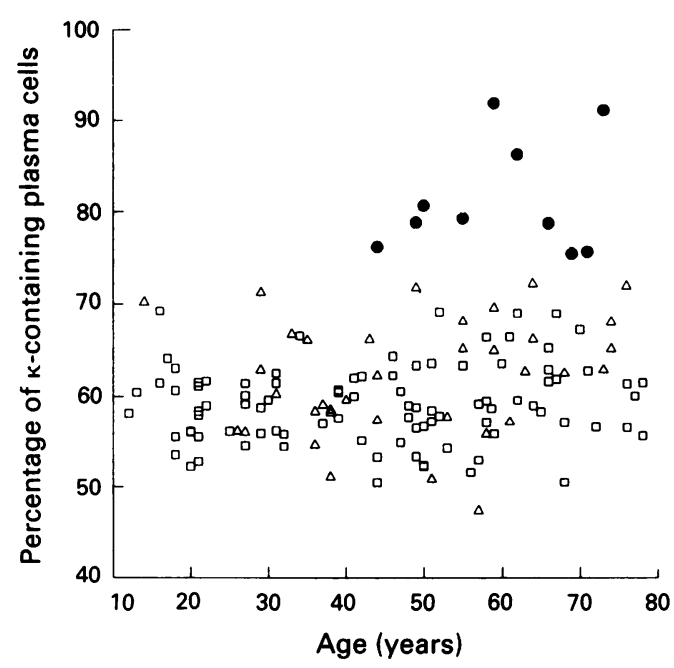

Figure 3 Scatter diagram of \% containing plasma cells compared with age of all subjects in this study.

oped systemic monoclonal gammopathy with circulating $\operatorname{IgM} / \kappa$ six months and six years, respectively, after the labial salivary gland tissue biopsy had been performed (cases 6 and 10 in table 6). In both cases the circulating paraprotein was identical with that of the immunoglobulin found in the labial salivary gland tissue. In one of these patients Bence Jones $(\kappa)$ protein was also found in the urine (case 2 in table 6). In a third patient (case 10 in table 6 ), with an excess of $\kappa$ containing plasma cells in the labial salivary gland tissue, malignant lymphoma (polymorphic immunocytoma, $\operatorname{IgM} / \lambda$ ) of the lung was diagnosed one year after the labial salivary gland tissue biopsy. In this patient, however, monotypic $\mathrm{IgG} / \kappa \mathrm{B}$ cell expansion in the labial salivary gland tissue was suspected on the basis of the immunoperoxidase staining results. All three patients had primary Sjögren's syndrome.

The median follow up period in the group of 10 patients with Sjögren's syndrome with an abnormal $\% \kappa$ in the labial salivary gland tissue was three years (range 1.5-9.5 years). None of the patients with normal $\% \kappa$ in the labial salivary gland tissue had developed systemic monoclonal gammopathy or malignant lymphoma after a median follow up period of 4.5 years (range 1-11 years). In the group of patients with Sjögren's syndrome with $\% \kappa$ of $\geqslant 75 \%$ the disease progressed into a systemic monoclonal process or malignant lymphoma significantly more often $(p=0.008)$.

\section{Discussion}

This study shows, for the first time, the occurrence of high percentages of $\kappa$ light chain containing plasma cells, due to the presence of monotypic plasma cell populations, in the labial salivary gland tissue of 10 of our 45 (22\%) patients with Sjögren's syndrome but without evidence of systemic monoclonal lymphoproliferative disease at the time of labial 
Table 6 Serological and immunohistopathological results of group IILA

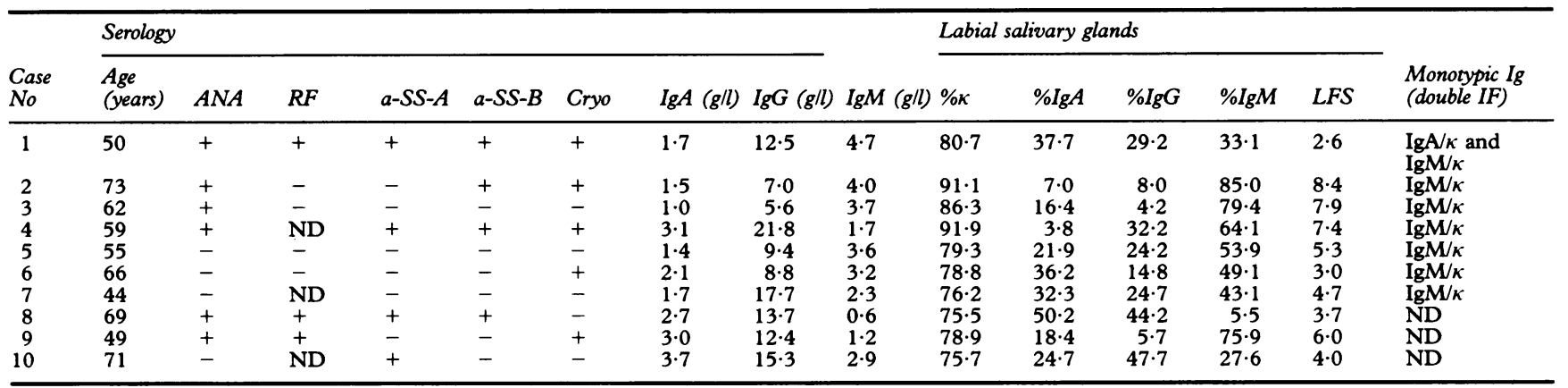

ANA = antinuclear antibody; RF = rheumatoid factor; a-SS-A = antibodies against SS-A; a-SS-B = antibodies against SS-B; Cryo = cryoglobulinaemia; \% $\kappa$, \%IgA, $\%$ IgG, \%IgM = percentages of $\kappa$, IgA, IgG, and IgM containing plasma cells; LFS = lymphocytic focus score; monotypic Ig = monotypic immunoglobulin; Double $\mathrm{IF}=$ double immunofluorescence labelling; $\mathrm{ND}=$ not done; Normal values are: IgA $0 \cdot 3-2 \cdot 5 \mathrm{~g} / \mathrm{l}$, IgG 4.7-13.3 g/l, IgM $0 \cdot 4-2 \cdot 4 \mathrm{~g} /$. Cases 2 and $7 \mathrm{had}$ secondary Sjögren's syndrome.

salivary gland tissue biopsy. Although systemic lymphoproliferative disorders are sometimes considered to be related to primary Sjögren's syndrome, ${ }^{3}$ this could not be validated. Of special clinical interest is our observation that progression into systemic monoclonal gammopathy or malignant lymphoma exclusively occurred in the subgroup of patients with Sjögren's syndrome with monotypic plasma cell populations, defined by a $\kappa: \lambda$ ratio of $\geqslant 3$.

Our findings agree with those obtained from immunohistological studies ${ }^{112}$ of the benign lymphoepithelial lesion of the major salivary glands, which is closely related to Sjögren's syndrome. ${ }^{21}$ These studies showed that extrasalivary gland lymphoma occurred exclusively in patients with a benign lymphoepithelial lesion with monotypic proliferation areas and not in those with polytypic proliferation areas. A report of myoepithelial sialadenitis (benign lymphoepithelial lesion) of the major salivary glands with proliferations of B cells with monotypic cytoplasmatic immunoglobulins has been considered to be a neoplastic lesion, and mentioned an early lymphoma. ${ }^{112}$

The monoclonal origin of the monotypic plasma cells in autoimmune sialadenitis has been confirmed by immunoglobulin gene rearrangement studies. $^{223}$ Fishleder et al found in benign lymphoepithelial lesions of parotid and submandibular gland, removed two years later from the same patient with Sjögren's syndrome, that the rearrangements of the heavy chain and $\kappa$ light chain genes were entirely different, ${ }^{22}$ making it highly unlikely that the $\mathrm{B}$ cell clone identified in the second lesion evolved from the first. Different immunoglobulin gene rearrangements in the same patient with benign lymphoepithelial lesions of different major salivary glands have also been observed by Freimark et al. ${ }^{23} \mathrm{We}$ did not perform immunoglobulin gene rearrangement studies due to shortage of tissue. However, our observation that multiple separated minor salivary glands of a labial salivary gland tissue biopsy specimen are populated by monotypic plasma cells of the same isotype $(\operatorname{IgM} / \kappa)$ or even of different isotypes in different glands in one of our patients $(\operatorname{IgM} / \kappa$ and $\operatorname{IgA} / \kappa)$ supports the hypothesis that monotypic plasma cell populations in the salivary glands of patients with Sjögren's syndrome are not the result of a clonal expansion of a single neoplastic changed lymphoid stem cell. Our observation of equal mean total numbers of $\kappa$ and $\lambda$ containing plasma cells per $0.04 \mathrm{~mm}^{2}$ of labial salivary gland tissue in the two groups of patients with Sjögren's syndrome also argues against the assumption of neoplastic $B$ cell proliferation in patients with monotypic plasma cell populations. More convincing support can be found in our observation that an $\operatorname{IgM} / \lambda$ polymorphic immunocytoma of the lung developed in a patient with Sjögren's syndrome and with predominance of $\mathrm{IgG} / \kappa$ containing plasma cells in the labial salivary gland tissue.

In our study all subjects with $\% \kappa$ of $\geqslant 75$ were patients with Sjögren's syndrome and older than 43 years. If there was no age preference for the occurrence of monotypic plasma cell infiltrates in patients with Sjögren's syndrome one could expect that four of our 18 patients younger than 43 years would also exhibit this phenomenon. In group II (patients with RA) the age distribution pattern resembled that of the group with Sjögren's syndrome with monotypic plasma cell populations (group IIIA). However, none of these patients with RA had a $\% \kappa$ of $\geqslant 75$, but about $50 \%$ of these patients had lymphocytic adenitis with a focus score of $>1$, mimicking the sialadenitis of Sjögren's syndrome.

All aforementioned observations support the hypothesis that monotypic plasma cell populations appear after a latency period in the labial salivary gland tissue and probably also in other exocrine glands in some patients with Sjögren's syndrome and with an initial polytypic plasma cellular infiltrate. This switch from a polytypic into a monotypic plasma cell infiltrate in many different glands cannot be attributed to neoplastic changes. A more likely explanation is that the exocrine glands in a subpopulation of patients with Sjögren's syndrome are homed by primitive B cells, which are liable to homeostatically regulated clonal expansions after prolonged antigenic stimulation by modified parenchymal cells in the target organs, and that this phenomenon is accompanied by an increased risk to develop systemic monoclonal lymphoproliferative disorders. On the basis of several studies B 
lymphocytes expressing CD5 antigen which are related to autoantibody production and monoclonal expansions, ${ }^{24-26}$ are a serious candidate.

In summary, the results of the present study and those of Schmid et al $^{11}$ show that patients with Sjögren's syndrome and monotypic B cell populations in their salivary glands are at increased risk of developing systemic monoclonal lymphoproliferative disorders. Knowing that the relative risk of all patients with Sjögren's syndrome of developing malignant lymphoma is about 44 times higher than in the normal population, ${ }^{10}$ it can be assumed that the relative risk of the subgroup of such patients with monotypic $B$ cell populations in their salivary glands is considerably higher. We conclude that quantitative immunohistological examination of labial salivary gland tissue provides pathologists with a simple method to select those patients with an increased relative risk, at the time of labial salivary gland tissue biopsy of developing benign or malignant lymphoproliferative disorders.

This study was financially supported by a grant $(88 / C R / 104 / 90)$ from the Dutch League against Rheumatism (Het Nationaal Reumafonds).

1 Anderson LG, Talal N. The spectrum of benign to malignant lymphoproliferation in Sjögren's syndrome. Clin Exp Immunol 1971;9:199-221.

2 Strand V, Talal N. Advances in the diagnosis and concept of Sjögren's syndrome (autoimmune exocrinopathy). Bull Rheum Dis 1980;30:1046-52

3 Tzioufas AG, Moutsopoulos HM, Talal N. Lymphoid malignancy and monoclonal proteins. In: Talal N, Moutmalignancy and monoclonal proteins. In: Talal N, Moutsopoulos HM, Kassan SS, eds. Sjögren's syndrome. Clinical and immuno

4 Moutsopoulos HM, Chused TM, Mann DL, et al. Sjögren's syndrome (sicca syndrome): current issues. Ann Intern Med 1980;92:212-26.

5 Manthorpe $R$, Frost-Larsen $K$, Isager $H$, Prause JU. Sjögren's syndrome. A review with emphasis on immunological features. Allergy 1981;36:139-53.

6 Yamoaka K, Miyasaka N, Sato K, Okuda M, Nishioka K. B cell hyperresponsiveness in Sjögren's syndrome. Autoimmunity 1989;3:261-9.

7 Moutsopoulos HM, Manoussakis MN. Immunopathogenesis of Sjögren's syndrome: "facts and fancy". Autogenesis of Sjogren's syndro

8 Zulman J, Jaffe R, Talal N. Evidence that the malignant lymphoma of Sjögren's syndrome is a monoclonal B cell neoplasm. $N$ Engl f Med 1987;229:1215-20.

9 Díaz-Jouanen E, Ruiz-Argüelles GJ, Vega-Ortíz JM, Villareal G, Alarcón-Segovia D. From benign polyclonal to malignant monoclonal lymphoproliferation in a patient with primary Sjögren's syndrome. Arthritis Rheum 1981;24: 850-3.

10 Kassan SS, Thomas TL, Moutsopoulos HM, et al. Increased risk of lymphoma in Sjögren's syndrome. Ann Intern Med risk of lymphoma in

11 Schmid U, Helbron D, Lennert K. Development of malignant lymphoma in myoepithelial sialadenitis (Sjömalignant lymphoma in myoepithelial sialadenitis (Sjögren's synd

12 Hyjek E, Smith WJ, Isaacson PG. Primary B cell lymphoma of salivary glands and its relationship to myoepithelial sialadenitis. Hum Pathol 1988;19:766- 76.

13 Moutsopoulos HM, Tzioufas AG, Bai MK, Papadopoulos NM, Papadimitriou CS. Association of serum IgM $k$ monoclonicity in patients with Sjögren's syndrome with an increased proportion of kappa positive plasma cells infiltrating the labial minor salivary glands. Ann Rheum Dis 1990;49:929-31.

14 Arnett FC, Edworthy SM, Bloch DA, et al. The American Rheumatism Association 1987 revised criteria for the classification of rheumatoid arthritis. Arthritis Rheum 1988;31:315-24.

15 Van Bijsterveld OP. Diagnostic tests in the sicca syndrome. Arch Ophthalmol 1969;82:10-14.

16 Chisholm DM, Mason DK. Labial salivary gland biopsy in Sjögren's disease. $尹$ Clin Pathol 1968;21:656-60.

17 Greenspan JS, Daniels TE, Talal N, Sylvester RA. The histopathology of Sjögren's syndrome in labial salivary gland biopsies. Oral Surg 1974;37:217-29.

18 Bosman FT, Lindeman J, Kuiper G, van der Wal A, Kreunig $\mathrm{J}$. The influence of fixation on immunoperoxidase staining of plasma cells in paraffin sections of intestinal biopsy specimens. Histochemistry 1977;53:57-62.

19 Bodeutsch C, de Wilde PCM, van Houwelingen JC, et al. Influence of fixation and immunohistological technique on accuracy, precision and inter-observer reproducibility of plasma cell counting. Analyt Cell Pathol 1991;3: 299-310.

20 De Wilde PCM, Kater L, Baak JPA, van Houwelingen JC, Hené RJ, Slootweg PJ. A new and highly sensitive immunohistologic diagnostic criterion for Sjögren's syndrome. Arthritis Rheum 1989;32:1214-20.

21 Batsakis JG. The pathology of head and neck tumours: the lymphoepithelial lesion and Sjögren's syndrome, part 16. Head Neck Surg 1982;5:150-63.

22 Fishleder A, Tubbs $R$, Hesse B, Levine $H$. Uniform detection of immunoglobulin-gene rearrangement in benign lymphoepithelial lesions. $N$ Engl $f$ Med 1987; 316:1118-21.

23 Freimark B, Fantozzi R, Bone R, Bordin G, Fox R Detection of clonally expanded salivary gland lymphocytes in Sjögren's syndrome. Arthritis Rheum 1989;32: 859-69.

24 Youinou P, Mackenzie L, le Masson G, et al. CD5Expressing B lymphocytes in the blood and salivary glands of patients with primary Sjögren's syndrome. Autoimmun 1988;1:185-94.

25 Bataille R, Klein B, Durie BGM. The relationship between autoimmune states and B cell proliferations. $f$ Rheumatol 1989;16:1023-4.

26 Kipps TJ, Robbins BA, Tefferi A, Meisenholder G, Banks PM, Carson DA. CD5-positive B cell malignancies frequently express cross-reactive idiotypes associated with IgM autoantibodies. Am $\mathcal{F}$ Pathol 1990;136:809-16. 